\title{
Effects of Temperature and Gibberellin Treatment on Seed Germination Characteristics of Caryopteris incana (Thunb.) Miq.
}

Xiaohua Shi $\unrhd$, Guangying Ma, Liang Jin, Qingcheng Zou

Zhejiang Institute of Landscape Plants and Flowers, Hangzhou, 311251, China

$\bigvee$ Corresponding author email: shxh2004@163.com

Medicinal Plant Research, 2022, Vol.12, No.1 doi: $\underline{10.5376 / \mathrm{mpr} .2022 .12 .0001}$

Received: 06 Jan., 2022

Accepted: 15 Jan., 2022

Published: 29 Jan., 2022

Copyright $(2022$ Shi et al., This article was first published in Molecular Plant Breeding in Chinese, and here was authorized to translate and publish the paper in English under the terms of Creative Commons Attribution License, which permits unrestricted use, distribution, and reproduction in any medium, provided the original work is properly cited.

Preferred citation for this article:

Shi X.H., Ma G.Y., Jin L., and Zou Q.C., 2022, Effects of temperature and gibberellin treatment on seed germination characteristics of Caryopteris incana (Thunb.) Miq., Medicinal Plant Research, 12(1): 1-6 (doi: 10.5376/mpr.2022.12.0001)

\begin{abstract}
Caryopteris incana (Thunb.) Miq. is an excellent ornamental, nectariferous plant and medicinal plant as a widely distributed species of the Caryopteris. Based on the determination of the length, width, 1000 -grain weight and water absorption of vanilla seeds, the effects of temperature and gibberellin treatment on seed germination were explored. The results showed that the average length and width of the seeds were $2.43 \mathrm{~mm}$ and $1.94 \mathrm{~mm}$. The 1000 -grain weight of the seeds was $0.57 \mathrm{~g}$. The seed reached saturation after 4 hours of water absorption. Seeds can germinate at $15^{\circ} \mathrm{C} \sim 30^{\circ} \mathrm{C}$ and hardly germinated above $35^{\circ} \mathrm{C}$. The optimal temperature for germination is $20^{\circ} \mathrm{C} \sim 25^{\circ} \mathrm{C}$. Gibberellin treatment can significantly improve the germination rate of Cyperus angustifolia, especially under the conditions of low temperature $\left(15^{\circ} \mathrm{C}\right)$ and high temperature $\left(35^{\circ} \mathrm{C}\right), 100 \sim 200 \mathrm{mg} / \mathrm{L}$ gibberellin treatment can improve the germination rate and shorten the germination period of the seeds. This study provides important theoretical support for the sowing and propagation of $C$. incana, and the theoretical basis for the planting and breed improvement of $C$. incana in the future.
\end{abstract}

Keywords Caryopteris incana (Thunb.) Miq.; Seed; Temperature; Gibberellin; Germination

Caryopteris incana (Thunb.) Miq. is a plant of the genus Caryopteris in Verbenaceae It is a tufted erect deciduous semi-shrub with light blue or lavender corolla, flowering from August to October. It has strong adaptability, which is the most widely distributed species of the Caryopteris. And it is an excellent landscaping and fragrance plant in summer and autumn (Chen, 2009).

Seed germination is a key link in plant population renewal and species continuation, and temperature is one of the important environmental factors affecting seed germination (Huang et al., 2021). Low temperature and high temperature can inhibit the germination of many plant seeds, only the appropriate temperature can promote seed germination. Gibberellin acid (GAs) is an important growth regulating hormone in the process of plant seed germination, which has strong physiological activity and can promote seed germination (Li et al., 2013). Different plant seeds have different sensitivity to exogenous gibberellin. It is of great significance to explore the appropriate concentration of gibberellin for seed germination (Du et al., 2019).

Foreign scholars have conducted a comprehensive study on Caryopteris incana, while it is rarely reported in China that Caryopteris incana is used as an ornamental plant in flower border, garden, cut flower and flower sea. The research on Caryopteris incana in China mainly focuses on the medicinal chemical constituents (Chen et al., 2004; Wang, 2016), growth characteristics (Chen, 2009), adaptability (Zhao, 2014) and tissue culture (Zhang et al., 2008). These studies focused on revealing the growth and asexual reproduction characteristics of Caryopteris incana. In addition to cutting and tissue culture, Caryopteris incana also can be sowed and propagated. However, there was no report on the effect of temperature and gibberellin on the seed germination of Caryopteris incana.

In this study, based on the determination of the morphology and water absorption characteristics of Caryopteris incana seeds, the effects of temperature single factor and gibberellin with temperature double factors on seed 
germination were explored. And the effects of gibberellin treatment on seed germination of Caryopteris incana under high and low temperatures and suitable temperature conditions were mainly studied, so as to expand the germination conditions required for germination of Caryopteris incana, find a simple and feasible seed germination method, shorten the seed germination cycle and improve the seed germination rate. This study provides important theoretical support for the sowing and propagation of $C$. incana, and the theoretical basis for the planting and breed improvement of $C$. incana in the future.

\section{Results and Analysis}

\subsection{Analysis of seed morphological variation}

The seeds of $C$. incana were obovate sphere capsule, covered with treelike hair, yellowish-brown, and divided into four mericarps after fruit maturation. The mericarps had wide wings, and the ventral surface was concave into holes to hold the seeds. The seed length was $2.43 \mathrm{~mm}$, the standard deviation was 0.16 , and the coefficient of variation was $6.63 \%$. The average width was $1.94 \mathrm{~mm}$ and the standard deviation was 0.10 . The seed width is consistent and the coefficient of variation was $5.40 \%$. The aspect ratio was 1.26 , the standard deviation was 0.09 , and the coefficient of variation was $7.17 \%$. The 1000 -grain weight was $0.57 \mathrm{~g}$, the weight of seed particles was uniform, and the coefficient of variation was $4.92 \%$ (Table 1 ).

Table 1 Morphological variation of Caryopteris incana seeds

\begin{tabular}{|c|c|c|c|c|c|}
\hline Character & Average value (g) & Standard deviation & Maximum value & Minimum value & Coefficient of variation $(\%)$ \\
\hline Length (mm) & 2.43 & 0.16 & 2.70 & 2.11 & 6.63 \\
\hline Width (mm) & 1.94 & 0.10 & 2.15 & 1.73 & 5.4 \\
\hline Aspect ratio & 1.26 & 0.09 & 1.41 & 1.10 & 7.17 \\
\hline Thousand seed weight (g) & 0.57 & 0.03 & 0.59 & 0.51 & 4.92 \\
\hline
\end{tabular}

\subsection{Water absorption capacity of seeds}

The water absorption of Caryopteris incana seeds was the fastest in $1 \sim 3 \mathrm{~h}$ (Figure 1), and the water absorption was $0.1204 \mathrm{~g}$. This stage is the imbibitional absorption of water before seed germination, and the water absorption of this stage is not related to seed metabolism. Seeds can absorb water whether they have completed dormancy or activity. The water absorption at the stage of imbibitional absorption of water was 2.08 times of the weight of air-dried seeds, mainly because the Caryopteris incana seeds had a thin and light wing-shaped edge, which had a large amount of water absorption, and the seed coat was as thin as paper, which was easy to absorb water and swell. After $4 \mathrm{~h}$ of seed water absorption, the water absorption was saturated. Even if the seed was kept in water for $12 \mathrm{~h}$, the weight was no longer increased. At this stage, the seed water absorption was slow, the hydration degree of protoplasts tended to be saturated, and the increase of seed volume was limited by the seed coat. Therefore, before the radicle broke through the seed coat, the seed water absorption had a stage of slow or suspended water absorption. It can be seen that the saturated water absorption of Caryopteris incana seeds is $0.1298 \mathrm{~g}$, which is 2.25 times that of air-dried seeds.

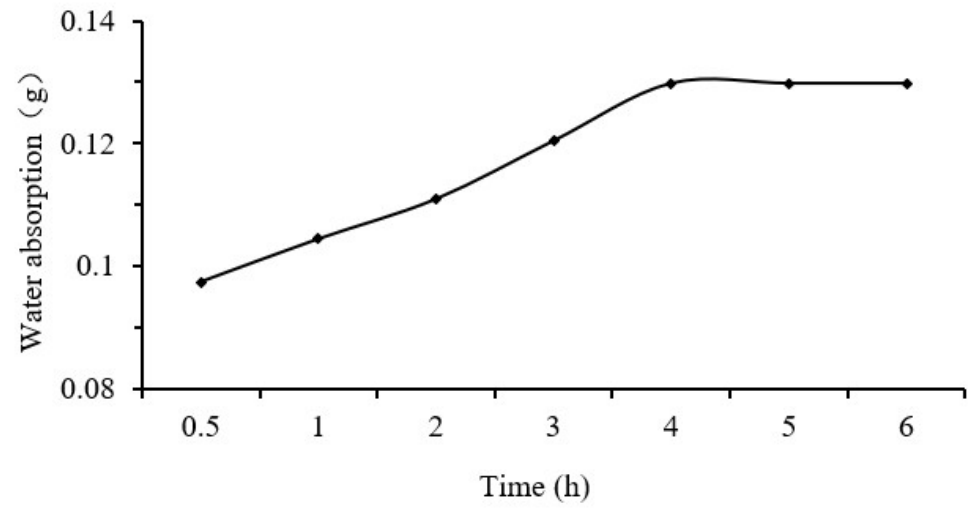

Figure 1 The water absorption capacity of Caryopteris incana 


\subsection{Effects of temperature on seed germination}

Caryopteris incana seeds can germinate at $15^{\circ} \mathrm{C} \sim 30^{\circ} \mathrm{C}$ and hardly germinated above $35^{\circ} \mathrm{C}$ (Table 2). Germination rate at $20^{\circ} \mathrm{C}$ and $25^{\circ} \mathrm{C}$ was $53 \%$ and $45.33 \%$, respectively. The seeds began to germinate on the $3^{\text {rd }}$ day, and the germinative force on the $7^{\text {th }}$ day was $38.67 \%$ and $36 \%$, respectively. There was no significant difference in germinative force, germination rate and germinative index. Low temperature of $15^{\circ} \mathrm{C}$ delayed seed germination, the seeds began to germinate on the $6^{\text {th }}$ day, and the germinative force was only $6 \%$ on the $7^{\text {th }}$ day. Although the germination rate could reach $51.25 \%$ on the $20^{\text {th }}$ day, the germination time was relatively long, and the germination period was also greatly increased, from $7 \sim 10 \mathrm{~d}$ at the optimum temperature $\left(20^{\circ} \mathrm{C} \sim 25^{\circ} \mathrm{C}\right)$ to $16 \sim 25 \mathrm{~d}$. With the increase of germination temperature, the germinative force and germination rate did not show a rising state, but at $30^{\circ} \mathrm{C}$, the germination rate and germinative force decreased significantly, and the germination rate was $39 \%$, which was significantly different from the temperature (about $20^{\circ} \mathrm{C}$ ) of the season in which the Caryopteris incana seeds in field begin to germinate in large quantities. Germination rate, germinative force and germinative index of seeds at different temperatures showed that Caryopteris incana germinate fastest, neatest and best at $20^{\circ} \mathrm{C} \sim 25^{\circ} \mathrm{C}$. The low temperature and high temperature during seed germination may inhibit seed germination to varying degrees, which is similar to Caryopteris mongholica (Guo, 2009).

There was no dormancy in the Caryopteris incana seeds. The seeds harvested from the plants that were sowed and grown in that year could germinate in the climate chamber of $15^{\circ} \mathrm{C} \sim 30^{\circ} \mathrm{C}$, which was basically consistent with the germination characteristics of Caryopteris mongolica Bunge. (Guo, 2009). But temperature has great influence on germination rate, germinative force and germinative index. Low temperature germination takes a long time, and high temperature leads to no germination of seeds.

Table 2 Effects of different temperature treatments on the seed of Caryopteris incana

\begin{tabular}{llll}
\hline $\operatorname{Tm}\left({ }^{\circ} \mathrm{C}\right)$ & Germination rate $(\%)$ & Germinative force $(\%)$ & Germinative index $(\%)$ \\
\hline 15.00 & $17.00 \pm 1.73 \mathrm{c}$ & $5.67 \pm 2.52 \mathrm{c}$ & $2.14 \pm 0.29 \mathrm{c}$ \\
20.00 & $53.00 \pm 3.46 \mathrm{a}$ & $38.67 \pm 3.51 \mathrm{a}$ & $8.95 \pm 0.62 \mathrm{a}$ \\
25.00 & $45.33 \pm 4.16 \mathrm{ab}$ & $36.00 \pm 3.61 \mathrm{a}$ & $8.04 \pm 0.64 \mathrm{ab}$ \\
30.00 & $39.00 \pm 3.00 \mathrm{~b}$ & $28.00 \pm 3.00 \mathrm{~b}$ & $6.82 \pm 0.51 \mathrm{~b}$ \\
35.00 & $4.67 \pm 3.06 \mathrm{~d}$ & $0.67 \pm 1.15 \mathrm{c}$ & $0.55 \pm 0.34 \mathrm{~d}$ \\
\hline
\end{tabular}

Note: Different lower cases in the same column indicate significant differences among treatments at 0.05 level

\subsection{Effects of gibberellin treatment on seed germination}

Based on the germination experiment of temperature on Caryopteris incana seeds, we can see that the optimal temperature for germination is $20^{\circ} \mathrm{C} \sim 25^{\circ} \mathrm{C}$ (Table 3). Placed the seeds at constant temperatures of $20^{\circ} \mathrm{C}$ and $25^{\circ} \mathrm{C}$. At $20^{\circ} \mathrm{C}, 100 \sim 400 \mathrm{mg} / \mathrm{L}$ gibberellin solution was used to treat the Caryopteris incana seeds, and the germination rate and germinative index were significantly different from those of the control. There was no significant difference in the effect of gibberellin concentration on the germinative force of Caryopteris incana seeds. Among them, the germination rate of Caryopteris incana seeds with $200 \mathrm{mg} / \mathrm{L}$ gibberellin treatment was as high as $81.67 \%$ within $10 \mathrm{~d}$, which was significantly higher than that of the control and $100 \mathrm{mg} / \mathrm{L}$ gibberellin treatment. Gibberellin treatment would significantly improve the germination rate of Caryopteris incana seeds. However, with the increase of gibberellin concentration, seed germination rate, germinative force and index did not always show an increasing trend, but slowly decreased, which was consistent with most other seeds.

At $25^{\circ} \mathrm{C}$, the germinative index of Caryopteris incana seeds with different concentrations of gibberellin was significantly different from that of the control $(p<0.5)$. The germination rate of Caryopteris incana seeds with $100 \mathrm{mg} / \mathrm{L}$ gibberellin treatment could reach $75 \%$, which was 1.67 times that of the control. There was no significant difference in the germination rate between $100 \mathrm{mg} / \mathrm{L}$ and $200 \mathrm{mg} / \mathrm{L}$ gibberellins treatment. In practice, $100 \mathrm{mg} / \mathrm{L}$ gibberellin solution could be used to treat the seeds at about $25^{\circ} \mathrm{C}$, so as to improve the germination rate, germinative force and index of Caryopteris incana. 
Comprehensive comparison, under the condition of $20^{\circ} \mathrm{C}$ and $25^{\circ} \mathrm{C}, 100 \sim 200 \mathrm{mg} / \mathrm{L}$ gibberellin can be used to treat the Caryopteris incana seeds according to the sowing season in practice, with the increase of temperature, the concentration of gibberellin can be reduced.

Table 3 Effects of different $\mathrm{GA}_{3}$ concentrations on the seed of Caryopteris incana at $20^{\circ} \mathrm{C} \sim 25^{\circ} \mathrm{C}$

\begin{tabular}{lllll}
\hline $\mathrm{Tm}\left({ }^{\circ} \mathrm{C}\right)$ & $\mathrm{GA}_{3}(\mathrm{mg} / \mathrm{L})$ & Germination rate $(\%)$ & Germinative force $(\%)$ & Germinative index $(\%)$ \\
\hline $20^{\circ} \mathrm{C}$ & 0 & $53 \pm 3.4641 \mathrm{c}$ & $38.67 \pm 3.51 \mathrm{a}$ & $8.95 \pm 0.62 \mathrm{c}$ \\
& 100 & $66.67 \pm 2.89 \mathrm{~b}$ & $51 \pm 5.19 \mathrm{a}$ & $11.16 \pm 0.72 \mathrm{~b}$ \\
& 200 & $81.67 \pm 4.04 \mathrm{a}$ & $55.67 \pm 10.02 \mathrm{a}$ & $13.49 \pm 0.61 \mathrm{a}$ \\
& 300 & $79.67 \pm 4.16 \mathrm{a}$ & $57.33 \pm 8.39 \mathrm{a}$ & $13.34 \pm 0.69 \mathrm{a}$ \\
& 400 & $74 \pm 6.08 \mathrm{ab}$ & $51.33 \pm 6.51 \mathrm{a}$ & $12.16 \pm 0.66 \mathrm{ab}$ \\
& 0 & $45.33 \pm 4.16 \mathrm{c}$ & $36.00 \pm 3.61 \mathrm{~b}$ & $8.04 \pm 0.64 \mathrm{c}$ \\
& 100 & $75.00 \pm 2.65 \mathrm{a}$ & $60.33 \pm 1.15 \mathrm{a}$ & $12.37 \pm 0.34 \mathrm{a}$ \\
& 200 & $73.67 \pm 2.52 \mathrm{a}$ & $39.67 \pm 11.93 \mathrm{ab}$ & $10.23 \pm 0.75 \mathrm{~b}$ \\
& 300 & $62.00 \pm 6.08 \mathrm{~b}$ & $25.00 \pm 11.36 \mathrm{~b}$ & $8.32 \pm 1.35 \mathrm{bc}$ \\
& 400 & $58.00 \pm 2.00 \mathrm{~b}$ & $19.67 \pm 4.04 \mathrm{~b}$ & $8.12 \pm 0.38 \mathrm{c}$ \\
\hline
\end{tabular}

At $15^{\circ} \mathrm{C}$, the germination rate of Caryopteris incana seeds with $300 \mathrm{mg} / \mathrm{L}$ gibberellin treatment could reach $56.67 \%$, which was 3.33 times that of the control. Subsequently, the seed germination rate was as high as $90 \%$ on the $16^{\text {th }}$ day. There was no significant difference in germination rate and germinative index between 200 $\mathrm{mg} / \mathrm{L}$ and $300 \mathrm{mg} / \mathrm{L}$ gibberellin treatment, but the germination rate of $100 \mathrm{mg} / \mathrm{L}$ gibberellin treatment was significantly different. In practice, under the conditions of $15^{\circ} \mathrm{C}, 200 \mathrm{mg} / \mathrm{L}$ gibberellin treatment can significantly improve the germination rate of the seeds. At $35^{\circ} \mathrm{C}$, the seeds without gibberellin treatment did not germinate. However, the germination rate of the seeds treated with $200 \mathrm{mg} / \mathrm{L}$ gibberellin was still as high as $72.01 \%$, which completely broke the inhibition of high temperature on the germination of Caryopteris incana seeds (Table 4).

Table 4 Effects of different $\mathrm{GA}_{3}$ concentrations on the seed of Caryopteris incana at $15^{\circ} \mathrm{C}$ and $35^{\circ} \mathrm{C}$

\begin{tabular}{lllll}
\hline $\mathrm{Tm}\left({ }^{\circ} \mathrm{C}\right)$ & $\mathrm{GA}_{3}(\mathrm{mg} / \mathrm{L})$ & Germination rate $(\%)$ & Germinative force $(\%)$ & Germinative index $(\%)$ \\
\hline $15^{\circ} \mathrm{C}$ & 0 & $17.00 \pm 1.73 \mathrm{c}$ & $5.67 \pm 2.52 \mathrm{ab}$ & $2.14 \pm 0.29 \mathrm{c}$ \\
& 100 & $34.67 \pm 7.09 \mathrm{~b}$ & $9.33 \pm 1.53 \mathrm{a}$ & $4.30 \pm 0.83 \mathrm{~b}$ \\
& 200 & $52.67 \pm 4.51 \mathrm{a}$ & $10.33 \pm 2.08 \mathrm{a}$ & $6.10 \pm 0.34 \mathrm{a}$ \\
& 300 & $56.67 \pm 5.13 \mathrm{a}$ & $10.67 \pm 3.21 \mathrm{a}$ & $6.82 \pm 0.58 \mathrm{a}$ \\
$35^{\circ} \mathrm{C}$ & 400 & $51.00 \pm 1.73 \mathrm{a}$ & $3.00 \pm 1.00 \mathrm{~b}$ & $5.90 \pm 0.19 \mathrm{a}$ \\
& 0 & $2.67 \pm 3.06 \mathrm{~b}$ & $0.57 \pm 1.15 \mathrm{c}$ & $0.35 \pm 0.34 \mathrm{c}$ \\
& 100 & $66.41 \pm 4.08 \mathrm{a}$ & $47.49 \pm 6.62 \mathrm{a}$ & $10.67 \pm 1.12 \mathrm{ab}$ \\
& 200 & $72.01 \pm 10.26 \mathrm{a}$ & $56.26 \pm 4.98 \mathrm{a}$ & $11.98 \pm 1.68 \mathrm{a}$ \\
& 300 & $62.73 \pm 5.86 \mathrm{a}$ & $43.45 \pm 5.35 \mathrm{ab}$ & $10.05 \pm 1.14 \mathrm{ab}$ \\
\hline
\end{tabular}

In summary, gibberellin can be used to remove the inhibition of extreme temperature (high and low temperature) on the germination of Caryopteris incana seeds, to realize the annual sowing production of Caryopteris incana, thereby reducing the production cost of sowing and seedling, and realizing the production of open seedling directly in early spring and summer.

\section{Discussion}

The morphological characteristics of seeds are the result of long-term interaction between seeds and environment, which have an impact on seed germination rate. Yang et al. (2015) found that the seeds from different families and genera had different accessory structures, and the weight was quite different, which led to 
different germination rates. The Caryopteris incana seeds are obovate sphere capsule, seed appendages are wing-shaped mericarp, easy to spread with wind and water long distance, which is one of the reasons for the Caryopteris incana as a widely distributed species of Caryopteri. The 1000-grain weight of the seeds was 0.57 $\mathrm{g}$, with length of $2.43 \mathrm{~mm}$, width of $1.94 \mathrm{~mm}$. Chen (2009) found that the Caryopteris incana seeds were 2.45 $\mathrm{mm}$ in vertical diameter and $2.11 \mathrm{~mm}$ in transverse diameter. Ma (2007) found that the length and width of Caryopteris incana seeds were $1.5 \sim 2 \mathrm{~mm}$ and $1 \sim 1.5 \mathrm{~mm}$, respectively, and the 1000 -grain weight (including cotyledon) was $0.9339 \mathrm{~g}$. There are some differences in the 1000-grain weight, length and width of the seeds, which may be caused by the different water and fertilizer management and planting conditions of Caryopteris incana. The water absorption of Caryopteris incana seeds was concentrated within $1 \sim 3 \mathrm{~h}$ of soaking, and reached saturation after 4 hours of water absorption, indicating that Caryopteris incana was sensitive to water conditions, which was similar to the water absorption characteristics of the seeds of Caryopteris mongolica (Guo et al., 2014).

There was no dormancy in the Caryopteris incana seeds. The seeds harvested from the plants that were sowed and grown in that year could germinate in the climate chamber of $15^{\circ} \mathrm{C} \sim 30^{\circ} \mathrm{C}$. Temperature significantly affected seed germination rate, suitable temperature promoted seed germination. Caryopteris incana germinate fastest, neatest and best at $20^{\circ} \mathrm{C} \sim 25^{\circ} \mathrm{C}$. Low temperature germination takes a long time. And hardly germinated at high temperature. Low and high temperature can inhibit seed germination to a certain extent, and the seed germination rate can be greatly improved by gibberellin treatment. In practice, $100 \sim 200 \mathrm{mg} / \mathrm{L}$ gibberellin can be used to treat the Caryopteris incana seeds according to the temperature of the sowing season. When the temperature is low in spring, the germination rate of Caryopteris incana seeds with $200 \mathrm{mg} / \mathrm{L}$ gibberellin treatment was $52.67 \%$ within $10 \mathrm{~d}$, and more than $90 \%$ within $20 \mathrm{~d}$. High temperature season above $35^{\circ} \mathrm{C}$ in summer, the germination rate of Caryopteris incana seeds with $200 \mathrm{mg} / \mathrm{L}$ gibberellin treatment was $72.01 \%$ within $10 \mathrm{~d}$, which completely broke the inhibition of high temperature on the germination of Caryopteris incana seeds

\section{Materials and Methods}

\subsection{Experimental materials}

The Caryopteris incana seeds used in this experiment were collected from the Germplasm Resource Nursery of Zhejiang Institute of Landscape Plants and Flowers. The healthy and pest-free plants sown in spring 2019 were selected. In mid-November, the seeds were collected when most of the sepals turned yellowish-brown, then dried and stored at room temperature.

\subsection{Seed phenotypic characteristics and 1000-grain weight}

Selected 100 plump seeds randomly, and observed the color, shape and surface condition of seeds with magnifier. Measured the length and width with digital vernier calliper (Accuracy: $0.01 \mathrm{~mm}$ ), and calculated the aspect ratio.

The Caryopteris incana seeds are relatively small. So, the weight of 1000 seeds were measured directly. 1000 seeds were randomly selected from the sample and weighed by electronic balance. 9 repeated weighing values were recorded, and the average value, standard deviation and coefficient of variation were calculated.

\subsection{Determination of water absorption capacity of seeds}

Counted 1000 plump Caryopteris incana seeds randomly, repeated 3 times. First weighed the dry weight of the seeds, put them into a $2 \mathrm{~mL}$ centrifuge tube, and added distilled water, which passes through all the seeds. Then placed the centrifuge tube at $25^{\circ} \mathrm{C}$, and absorbed the seed surface moisture with absorbent paper every $0.5 \mathrm{~h}$ or $1 \mathrm{~h}$. Weighed continuously for many times until the data measured twice adjacent to each other were stable (Chen et al., 2019).

\subsection{Different temperature and gibberellin treatment}

After the pre-test, gibberellin solutions with concentrations of $100 \mathrm{mg} / \mathrm{L}, 200 \mathrm{mg} / \mathrm{L}, 300 \mathrm{mg} / \mathrm{L}$, and $400 \mathrm{mg} / \mathrm{L}$ 
were prepared, respectively. A total of 100 Caryopteris incana seeds were evenly spread into a $9 \mathrm{~cm}$ disposable plastic petri dish with filter paper. Each petri dish was poured into $6 \mathrm{~mL}$ gibberellin solutions with different concentrations, and water was used as the control. Repeated 3 times. And placed into climate chamber at $15^{\circ} \mathrm{C}$, $20^{\circ} \mathrm{C}, 25^{\circ} \mathrm{C}, 30^{\circ} \mathrm{C}$, and $35^{\circ} \mathrm{C}$, respectively, with $12 \mathrm{~h}$ darkness and $12 \mathrm{~h}$ light. The germinative force was counted on the $7^{\text {th }}$ day after planting, and the germination rate was counted on the $10^{\text {th }}$ day. To explore the optimal temperature and gibberellin solution concentration for seed germination.

Germinative force $(\%)=$ Number of seed germination of $7 \mathrm{~d} /$ Total number of experimental seeds $\times 100 \%$;

Germination rate $(\%)=$ Number of seed germination of $10 \mathrm{~d} /$ Total number of experimental seeds $\times 100 \%$;

(Germination standard: all germinated seeds are recorded as germination).

Germinative index $(\%)=\sum(\mathrm{Gt} / \mathrm{Dt})(\mathrm{Gt}$ means the number of seed germination per day, and $\mathrm{Dt}$ means the corresponding germination days).

\subsection{Data processing}

Data of experimental results were analyzed by Excel and DPS software.

\section{Authors' contributions}

SXH and MGY were the experimental designers and executor of this study. JL participated in data collation. ZQC participated in part of the experiment. SXH drafted and revised the manuscript. All authors read and approved the final manuscript.

\section{Acknowledgments}

This study was supported by the Hangzhou Agricultural Research Project of Zhejiang Province(20150432B37) and Major Science and Technology Program of Xiaoshan District, Zhejiang Province (2018228).

\section{Reference}

Chen C.L., 2009, Studing on the Biology characteristic and selective breeding for the superior individuals of Caryopteris incana, Thesis for M.S., Hunan Agricultural University, Supervisor: Wu T.M., pp.18

Chen H.M., Sun L.F., and Ye W.F., 2004, Studies on chemical constituents of the volatile oil from Caryopteris incana (Thunb.) Miq., Jinggangshan Shifan Xueyuan Xuebao (Journal of JinggangshanNomal College (Natural Sciences)), 25(6):5-8

Chen Y.J., Tang L., Jiang D.Y., Li Y.G., Liu X.H., 2019, Study on biological characteristics of Cerasus cam panulate Maxim., Zhongzi (Seed), 38(4): $70-73$

Du C.X., Wang J.L., Zhou H.K., and Yin H.X., 2019, Research progress on the effects of gibberellin on plant seed germination and seedling growth, Hubei Agricultural Sciences, 58(22): 9-14

Guo C.Y., H X., Liu G.H., Gao J.P., and Lu L.N, 2014, Effects of storage environment and time on seed germination of Caryopteris mongolicoBunge., Zhongzi (Seed), 33(6): 17-20

Guo C.Y., 2009, Study on reproductive biology of Caryopteris mongolico Bunge, Dissertation for Ph.D., Inner MongoliaUniversity, Supervisor: Liu G.H., and He X., pp.79-87

Huang H., Fu J.X., Cao B.H., Zhao W.X., Hao M.Z., Mao P.L., Wang T.T., Hao Y.D., Zhang X.H., and Tan H.T., 2021, Effects of salt stress and temperature on seed germination andseedling growth of Mows alba, Xinan Linye Daxue Xuebao (Journal of Southwest Forestry University), 41(1): $1-9$

Li D.L., Yin H.X., Liu H.C., Wang S.S., Peng W., and Yang X.L., 2013, Progress on gibberellins, gibberellins functional analogues and gibberellins receptor, Nongyaoxue Xuebao (Chinese Journal of Pesticide Science), 15(6): 601-608

Ma D.D., 2007, Study an introductian breeding and garden application of wild border flowers, Thesis for M.S., Zhejiang Foresty College, Supervisor: Li G.Y., pp.49-50

Wang X.Y., 2016, The identification analysis of Caryopteris Incana Herba, Thesis for M.S., Guangxi University of Chinese Medicine, Supervisor: Zhu H., pp. 1-24

Yang J.J., Wang J.J., NarkesWali, Ren A.T., and Lu W.h., 2015, Seed morphology and effect of sheep rumen digestion on germinability of 28 grass of Tianshan, Caoye Xuebao(ActaPratacultruraeSinica), 24(2): 104-115

Zhang Q.Y., Ma D.D., Chen R., Huang L.C., He Y.Y., and Li G.Y., 2008, Tissue culture and rapid propagation of Caryopteris incana (Thunb.) Miq., Zhiwu Shenglixue Tongxun (Plant Physiology Journal), 44(3): 535

Zhao C.L., 2014, A study of adaptability of common bluebeard herb in Ningxia, Ningxia Nonglin Keji (Ningxia Journal of Agriculture and Forestry Science and Technology), 55(1): 15-16 